\title{
Effect of Giving Different Doses of Vitamin E in Feed to the Level of Gonad Maturity of Tilapia (Oreochromis niloticus)
}

\author{
Gunawan Tarigan $^{1 *}$, I Wayan Arthana ${ }^{1}$, and Dewa Ayu Angga Pebriani ${ }^{1}$ \\ ${ }^{1}$ Department of Aquatic Resources Management, Faculty of Marine and Fisheries, Udayana University \\ Jl. Kampus Unud Bukit Jimbaran, Kuta Selatan, Badung, Bali \\ *Corresponding author: gunawantarigan00@gmail.com
}

\begin{abstract}
One of the nutrients that can be given to broodfeed fish to improve reproductive performance and egg quality is vitamin E. Vitamin $\mathrm{E}$ has a very important role in increasing fish reproduction because vitamin $\mathrm{E}$ functions as an antioxidant that can maintain the presence of fatty acids and prevent fat oxidation in the fish cell membrane and can accelerate the secretion of reproductive hormones. This study aims to determine the effect of vitamin $\mathrm{E}$ in feed at different doses on the level of gonad maturity of tilapia. The research was conducted at the Fisheries Laboratory of the Faculty of Marine and Fisheries, Udayana University from July to August 2020. The samples of fish tested were tilapia (Oreochromis niloticus) obtained from the Teratai fishing pond, Sanur Bali. Vitamin E used was Ovagrow vit E with a vitamin E content of 50\%. The CRD method (completely randomized design) was used with four treatments and three replications. The doses of vitamin E that were mixed into the feed were $0,100,300$ and $500 \mathrm{mg} / \mathrm{kg}$ of feed. The results showed that the administration of vitamin E mixed in the feed at different doses had a significant effect on the achievement of gonad maturity level, gonad somatic index (GSI), and Fecundity (P <0.05). Provision of vitamin $\mathrm{E}$ at a dose of $300 \mathrm{mg} / \mathrm{kg}$ of feed was the best dose for ripening tilapia gonads. The gonad maturity level developed up to maturity stage IV, the GSI value was $(3.56 \pm 0.46)$ and the fecundity value was $(1379 \pm 289)$.
\end{abstract}

Keywords: fecundity; gonad maturation; GSI; tilapia, vitamine E

\section{INTRODUCTION}

One way to obtain optimal fish hatchery results is by improving reproductive performance, which can be improved by improving the nutritional quality of broodstock feed. One of the nutrients that can be given to broodstock to improve reproductive performance and egg quality is vitamin E. Vitamin E has a very important and decisive role in fish reproduction. Vitamin $\mathrm{E}$ has a very important role in improving fish reproduction because vitamin $\mathrm{E}$ functions as an antioxidant that can maintain the presence of fatty acids and prevent fat oxidation in cell membranes and can accelerate the secretion of reproductive hormones [1]. The addition of vitamin $\mathrm{E}$ to comet fish feed (Carassius auratus) can increase the reproductive performance of these fish, such as increasing egg diameter, gonad maturity index, and fecundity [2]. Based on this, it is necessary to make efforts to improve reproductive performance and improve egg quality by adding nutrients in the form of vitamin $\mathrm{E}$ in broodstock feed.

The need for vitamin $\mathrm{E}$ as the main component in broodstock feed is known, and is different for each type of fish. The role of vitamin $\mathrm{E}$ in the reproductive performance of tilapia is not well known, although the use of vitamin $\mathrm{E}$ in research on tilapia species has been done. This study was conducted to evaluate the effect of vitamin $E$ on feed on the maturity level of the gonads and determine the best dose of vitamin $\mathrm{E}$ to accelerate the ripening of the gonads of tilapia (Oreochromis niloticus).

\section{METHODS}

Experimental setup

This research was conducted from July to August 2020. Maintenance and observation was carried out for 6 weeks with an initial age of the test fish ranging from 4 months, to determine the development of tilapia (Oreochromis niloticus) gonad maturity and check the water quality once a week. This research was carried out using fish cultivation techniques in bucket. Experimental design using CRD method (completely randomized design) was used with four treatments and three replications and used random sampling for each treatment and replication. The doses of vitamin $\mathrm{E}$ that were mixed into the feed were 0, 100, 300 and $500 \mathrm{mg} / \mathrm{kg}$ of feed.

\section{Materials}

The materials used in this study were tilapia with a size of \pm 200 grams as the test sample, commercial feed (HIPRO-VITE $781 \mathrm{~N}$ ) and vitamin E (Ovagrow Vit E) and water as a live medium. The tools used in this study were 
buckets, aerators, stationery, ruler, section set, digital scales, DO meter, pH meter, and thermometer.

\section{Water Quality Parameter}

Water quality was measured simultaneously with growth rate measurements, which was once every 1 weeks with in situ measurements. The variables measured include temperature, dissolved oxygen (DO), degree of acidity $(\mathrm{pH})$ and temperature.

\section{Data Analysis}

The research data was analyzed using One Way Analysis of Variance (ANOVA) and Duncan's advanced test with a significance level of 5\%. Testing on research results using Statistical Product and Service Solutions (SPSS) software. The variables measured included the Gonad somatic index and fecundity. Gonad somatic index of tilapia is calculated by the formula [3]:

$G S I=\frac{W G}{W} \times 100 \%$

Noted: GSI is the gonad somatic index of fish (\%), Wg is the weight of the gonad (gram), $\mathrm{W}$ is the weight of the body fish (gram).

Fecundity of tilapia is calculated used the formula [3]:

$F=\frac{G}{g} \times N$

Noted: $\mathrm{F}$ is the fecundity (grains), $\mathrm{G}$ is the total weight of the gonad (gram), $\mathrm{g}$ is the weight of the sampel gonad (gram), $\mathrm{N}$ is number of sampel eggs (grains).

survival rate of tilapia is calculated used the formula [3]:

$S R=\frac{N t}{N o} \times 100$

Noted: SR is fish survival (\%), Nt is the number of fish at the end of maintenance, No is the number of fish at the beginning of stocking.

\section{RESULT AND DISCUSSION}

\section{Gonad Maturity Level}

The results of observations in the study for 42 days showed that giving vitamin $E$ to fish feed had an impact on the gonad growth of tilapia. Different increases in gonad growth indicated that different doses of vitamin $\mathrm{E}$ in feed could affect gonad growth in tilapia. Gonad samples in treatment A (control) developed up to gonad maturity stage III with the characteristics of most of the gonads being dark red and the rest appearing pink. The gonads cover half of the abdominal cavity. Smooth egg grains begin to appear at the base of the gonads. At maturing stage III, the vitolegenesis process begins so that this level is also called the accumulation phase of egg yolk and gonad maturation.
Gonad samples in treatment B and C developed up to gonad maturity stage IV with morphological characteristics of the gonads covering almost the entire abdominal cavity. All gonads are dark red. The intestine is pressed and the egg granules are getting clearer. At this stage the eggs enter the final maturity stage, meaning that the fish are ready to be spawned. Meanwhile, the gonad sample of treatment D developed to maturing stage III with the same morphological characteristics as treatment A. Vitamin $\mathrm{E}$ is one of the important micronutrients that affects the reproductive performance of fish [4]. Vitamin $\mathrm{E}$ in feed will act as an antioxidant to maintain fatty acids from oxidation of fatty acids. The increasing the dose of vitamin $\mathrm{E}$ in the feed, the more the presence of fatty acids and the less chance of the fatty acids being oxidized during gonad development. The fatty acids that are retained by vitamin $\mathrm{E}$ will be used as the main ingredient (vitellogenin) during the egg yolk formation process (vitellogenesis). In accordance with the role of vitamin E as an antioxidant, unsaturated fatty acids in phospholipids in cell membranes are protected [5]. Lack and excess of vitamin E levels in feed can inhibit ovarian growth. From the above results it means that the provision of vitamin $\mathrm{E}$ has an effect on fish reproduction. Giving the right dose can have a positive impact on the reproduction of tilapia. Vitamin $\mathrm{E}$ supplementation to levels of $300 \mathrm{mg} / \mathrm{kg}$ feed tends to increase the reproductive quality of tilapia [6]. Gonad maturity can be identified in various ways, including by observing the histological structure and visually observing the morphology of the gonads. By comparing the gonad morphology visually with the literature listed, the results of the tilapia gonad maturity level are obtained in Table I.

\section{Gonad Somatic Index}

The GSI value is determined based on the percentage of gonad weight divided by the weight of the parent body. The highest value of the gonad somatic index (GSI) was found in fish treated $\mathrm{C}$ where the addition of vitamin $\mathrm{E}$ at a dose of $300 \mathrm{mg} / \mathrm{kg}$ of feed was $3.56 \%$ followed by fish that received treatment $\mathrm{B}(100 \mathrm{mg} / \mathrm{kg}$ of feed $)$ of $2.64 \%$, then fish that received treatment A (control) was $1.99 \%$ and the lowest GSI value was in treatment D $(500 \mathrm{mg} / \mathrm{kg}$ of feed) by $1.77 \%$. The difference in GSI values is believed to be influenced by differences in the provision of vitamin $E$ in different doses in each feed of the test fish. The data above shows that the reproduction of tilapia can be improved by adding vitamin $\mathrm{E}$ in the feed. Vitamin $\mathrm{E}$ is one of the micronutrients are indispensable and important role in the process of growth, reproduction, and health of fish [8].

Based on these results and the statistical tests that have been carried out on $95 \%$ confidence interval, administration of vitamin $\mathrm{E}$ in the treatment of a show 
influence significantly different from treatment $\mathrm{C}$ $(\mathrm{P}<0.05)$, but not significantly different from treatment $\mathrm{B}$ and D. Giving vitamin $\mathrm{E}$ with the right dose in the feed can increase the GSI value in tilapia. Giving vitamin $\mathrm{E}$ at a dose of $300 \mathrm{mg} / \mathrm{kg}$ of feed is the best dose in this study to accelerate the maturity of gonads in tilapia. Vitamin E supplementation up to levels of $300 \mathrm{mg} / \mathrm{kg}$ of feed tends to increase the reproductive quality of tilapia [6]. The increase in GSI value is thought to be due to the role of vitamin $\mathrm{E}$ in the process of gonad development, namely vitamin $\mathrm{E}$ affects the biosynthesis of vitelogonin or the vitellogenesis process in the liver. Fat oxidation that occurs when vitelogonin is prevented by vitamin $\mathrm{E}$ as an antioxidant against fat. This causes an increase in the number of vitellogenin at the time of the oocyte and increases the gonad weight so that the percentage of GSI becomes larger [9]. The increase in gonad weight also causes the GSI value to also increase. The increase in the value of GSI is due to an increase in the amount of vitellogenin in the vitellogenesis process which will be allocated to the gonads so that it can increase the value of GSI [2]. The optimal content of vitamin $E$ in the feed will speed up the vitellogenesis process so that the ripening process of the gonads will be faster. Vitelogenin is the yolk ovule which is the main component of the growing oocyte [10].

TABEL I

GONAD MATURITY LEVEL OF TILAPIA

\begin{tabular}{ccc}
\hline $\begin{array}{c}\text { Gonad } \\
\text { maturity } \\
\text { level }\end{array}$ & Sampel & Literature [6] \\
\hline I & - & \\
II &
\end{tabular}

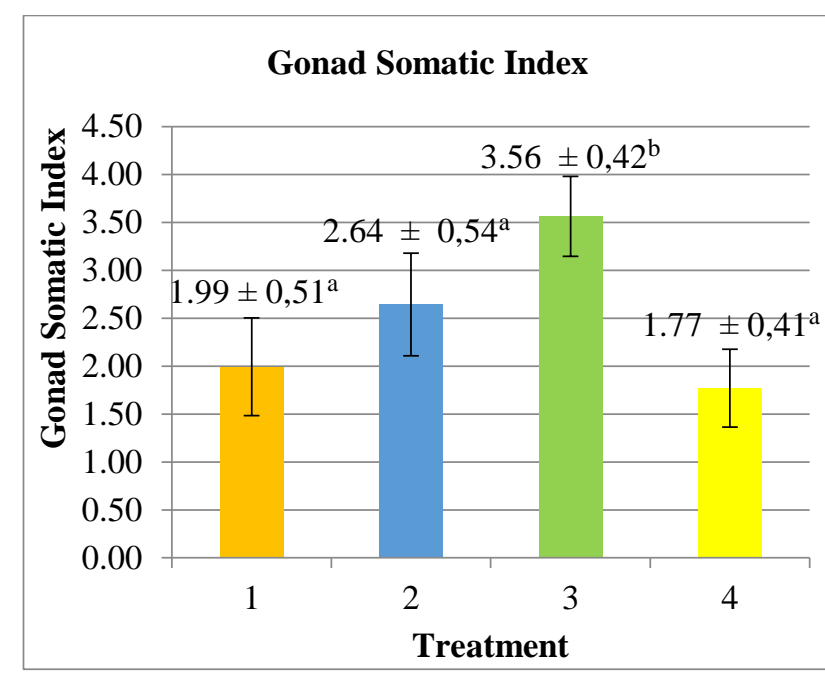

Figure 1. GSI (Gonad Somatic Index) of Tilapia

Fecundity

The fecundity value of treatment A was 555 items, treatment B was 973 items, treatment $\mathrm{C}$ was 1.379 items and treatment D was 540 items. Based on these data and through statistical tests that have been carried out with a 95\% confidence interval, administration of vitamin $\mathrm{E}$ in the treatment A showed a significantly different effect with treatment $\mathrm{B}$ and $\mathrm{C}(\mathrm{P}<0.05)$, but not significantly different from treatment $\mathrm{D}$.

Data and also the graph in figure 2, it can be seen that the highest fecundity value was found in treatment $\mathrm{C}$ which was 1,379 grains (Vitamin E $300 \mathrm{mg} / \mathrm{kg}$ of feed). This fecundity value is the highest compared to the fecundity value in other treatments. This proves that giving the right dose of vitamin $\mathrm{E}$ can increase the fecundity value in fish. Fecundity increases with the addition of vitamin $\mathrm{E}$ to feed [11]. Fecundity tends to increase with increasing content of vitamin $\mathrm{E}$ in feed [12]. The presence of vitamin $E$ in the feed can increase vitologen in the ovaries, which together can increase the formation of egg granules in the ovaries which affects the value of fish fecundity. The more vitellogenin material that will be absorbed by the ovaries during the reproductive phase causes the number of egg granules to form in the ovaries to increase [1]. Meanwhile, the lowest value for fecundity was found in treatment $D$ of 540 items (Vitamin E $500 \mathrm{mg} / \mathrm{kg}$ of feed). This indicates that excess vitamin $\mathrm{E}$ does not have a significant effect on fish gonad development. In other words, vitamin $\mathrm{E}$ in feed has an optimum dose of increasing fecundity in tilapia. Vitamin $\mathrm{E}$ is known to be a fat-soluble vitamin, which when given in high levels in feed will have a negative effect on fish [13]. So the best dose of vitamin E to increase the fecundity of tilapia is in treatment $\mathrm{C}$ with a dose of 300 $\mathrm{mg} / \mathrm{kg}$ of feed. 


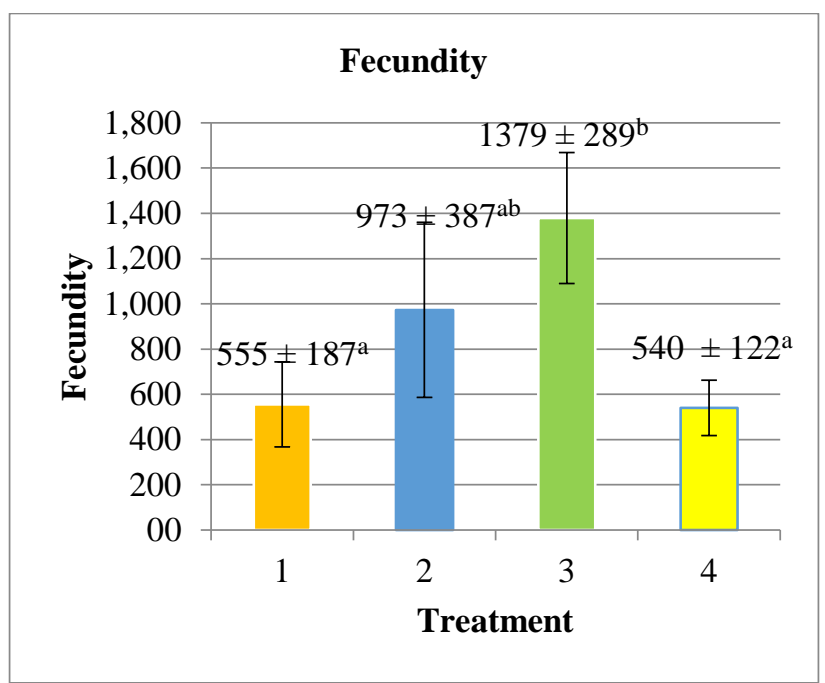

Figure 2. Fecundity of Tilapia

\section{Water quality}

In this study, the quality of water in the fish rearing media is maintained and controlled so that it is in good condition and suitable as a medium for fish rearing. Regular water changes, aeration is carried out to maintain the quality of the water in the fish culture media. During the maintenance period, the temperature ranges from $25^{\circ} \mathrm{C}-28^{\circ} \mathrm{C}$, the temperature range is said to be still optimal for the living medium and growth of tilapia. Conditions are still in accordance with SNI 7550: 2009, the temperature range is $25^{\circ} \mathrm{C}-32^{\circ} \mathrm{C}$. Tilapia can grow normally in the temperature range $14-38^{\circ} \mathrm{C}[14]$. The $\mathrm{pH}$ value of the water is in the range of 6.6-7.4 the $\mathrm{pH}$ value of the water is still suitable for use in tilapia fish farming and the conditions are still in accordance with SNI 7550: 2009, $\mathrm{pH}$ 6.5-8.5.

The suitable $\mathrm{pH}$ for tilapia maintenance is $6-8.5$, but optimal growth occurs at a $\mathrm{pH}$ of 7-8. The $\mathrm{pH}$ value that tilapia can tolerate is between 5-11 [15]. As well as the dissolved oxygen content in the range 3-3.5 ppm, the value of DO is classified as low but the conditions are still in accordance with SNI 7550: 2009, DO $\geq 3$. This range has met the oxygen needs for tilapia fish maintenance. The optimal growth of tilapia requires waters with an oxygen content of at least $3 \mathrm{mg} . \mathrm{L}^{-1}[15]$.

TABLE II

WATER QUALITY

\begin{tabular}{cccc}
\hline Treatment & $\begin{array}{c}\text { Temperature } \\
\left({ }^{\circ} \mathrm{C}\right)\end{array}$ & $\mathrm{pH}$ & $\mathrm{DO}(\mathrm{ppm})$ \\
\hline A & $25-27$ & $6,8-7,4$ & $3-3,5$ \\
B & $25-28$ & $6,6-7,2$ & $3-3,5$ \\
C & $25-28$ & $6,8-7,4$ & $3-3,5$ \\
D & $25-28$ & $6,8-7,4$ & $3-3,5$ \\
Standard & $14-38^{[14]}$ & $6-8,5^{[15]}$ & $\geq 3^{[15]}$ \\
\hline
\end{tabular}

Water quality parameters such as temperature, $\mathrm{pH}$ and DO greatly affect the viability of the test fish. The water quality is still decent and can be tolerated by the test fish. The water quality condition during the rearing period is classified as low and is at the lowest limit of the water quality standard for tilapia rearing but is still in a controlled and proper condition and can be tolerated by fish, which means that it does not have a negative effect on the growth and survival of the tested fish.

\section{CONCLUSION}

Based on the research results, giving vitamin $\mathrm{E}$ with different doses in fish feed had an influence on the development of gonad maturity, gonad maturity index and tilapia fecundity. Giving vitamin E as much as $300 \mathrm{mg} / \mathrm{kg}$ is the best dose. Provision of vitamin E at a dose of 300 $\mathrm{mg} / \mathrm{kg}$ of feed is the best dose for ripening tilapia gonads. The gonad maturity level developed up to maturity stage IV the GSI value was $(3.56 \pm 0.46)$ and the fecundity value was $(1379 \pm 289)$.

\section{ACKNOWLEDGE}

The author's gratitude goes to Mr. I Wayan Arthana and Mrs. Dewa Ayu Angga Pebriani as supervisor, who helps a lot in the field. Thank you to all parties who have guided and assisted the author in completing this research.

\section{REFERENCES}

[1] Napitu, R., S. Limin and Suparmono. 2013. Influence addition of vitamin $\mathrm{E}$ to starch-based feed trash fish against ripeness of tilapia gonads red (Oreocromis niloticus). Journal Eng. and Aqua. Technology. 1: 110-116.

[2] Arfah, H., Melati \& M. Setiawati. 2013. Vitamin E supplementation with different doses at feed on the reproductive performance of the female brood fish comet (Carassius auratus auratus). $J$. Aquaculture Indonesia. 12: 14-18.

[3] Effendie, Ichsan. 1997. Fisheries Biology. Bogor. Yayasan Pustaka Nusantama

[4] Gammanpila, M., Yakupitiyage, A., and Bart, AN 2007. Evaluation of the effects of dietary vitamin $\mathrm{C}$, E, and zinc supplementation on reproductive performance of nile tilapia (Oreochromis niloticus). Aqua. Science, 12: 39-60.

[5] Hamre, K. (2011). Metabolism, interactions, requirements and functions of vitamin $\mathrm{E}$ in fish. Aquaculture Nutrition, 17, 98-115.

[6] Sunarno., And Muhammad, F. 2004. Improvement Reproductive Quality of Tilapia (Oreochromis niloticus) through the addition of Vitamin E ( $\alpha$ Tocopherol) in Feed Formulations. Semarang: UNDIP.

[7] Wardani, Y., N. Mote and SL Merly. 2017. Aspects Reproduction of Tilapia (Oreochromis niloticus) in 
Rawa Biru, Sota District, Merauke Regency. Journal Fisherina, 1 (1): 1-10.

[8] Hunt, AO, Ozkan, F., and Altun, T. 2004. Effect of broodstock nutrition on reproductive performance of fish. Turkish Journal of Aquatic Life, 2 (3): 487-493.

[9] Tang, MU \& Affandi, R. 2004. Biology of reproduction fish. Research Center for Coastal and Aquatic Areas. Pekanbaru: Riau University, 110 p.

[10] Tang, MU and Affandi, R. 2000. Biology of reproduction fish. Bogor: Center for research and supervision waters. $110 \mathrm{p}$.

[11] Andri. 2006. Development of Fish Female Gonads Zebra Danio (Brachydanio rerio) who are given Feed with Various Doses of Vitamin E. Bogor: IPB.
[12] Aryani, N., Efawani \& A. Nur. 2014. Enrichment of artificial feed with vitamin $\mathrm{E}$ for gonadal maturation of mali fish (Labeobabarbus festivus). $J$. Fisheries and aquatic. 2: 126-129.

[13] Halver, JE 2002. The vitamins. In Halver, JE and Hardy, RW (Eds.). Fish Nutrition. 3rd Edition. San Diego CA, USA: Academic Press, p. 61-141.

[14] Khairuman and Khairul Amri. 2005. Fish Farming Indigo Intensively (Fourth Printing). Jakarta South: PT Agromedia Pustaka.

[15] Kordi, K.M.G.H. 2010. Complete guide keeps freshwater fish in a tarpaulin pond. Yogyakarta. Lily Publisher. 